\title{
Genealogia e historicismo crítico: dois modelos de Esclarecimento nos escritos de Horkheimer e Adorno*
}

\author{
Genealogy and critical historicism: two models of Enlightenment in \\ Horkheimer and Adorno's writings
}

\author{
John Abromeit \\ abromejd@buffalostate.edu \\ (State University of New York - Buffalo State, New York, United States)
}

\begin{abstract}
Resumo: Este artigo sustenta que dois conceitos distintos de Esclarecimento coexistem em tensão na Dialética do esclarecimento de Horkheimer e Adorno. De acordo com o primeiro conceito, genealógico, o Esclarecimento é uma forma confusa de autopreservação que existiu desde a aurora da civilização ocidental. O segundo conceito, historicista crítico, concebe como Esclarecimento os ideais críticos e antiautoritários articulados - mais radicalmente na França do século XVIII - durante o irregular desenvolvimento da sociedade burguesa moderna. Depois de examinar as origens destes dois conceitos nos primeiros escritos de Adorno e Horkheimer, este artigo demonstra porque o primeiro conceito se tornou dominante na Dialética do esclarecimento, ao mesmo tempo apontando traços significativos do segundo conceito que ali permaneceram. Argumenta-se que uma reconsideração do conceito historicista crítico revela um modelo de Teoria Crítica inicial que ainda pode fornecer uma alternativa convincente não apenas para a Dialética do esclarecimento, mas também para as tentativas mais recentes de situar a Teoria Crítica em fundamentos normativos.
\end{abstract}

Palavras-chave: Esclarecimento; historicismo; Max Horkheimer; Theodor Adorno; Escola de Frankfurt.
Abstract: This article argues that two distinct concepts of Enlightenment coexist uneasily in Horkheimer and Adorno's Dialectic of Enlightenment. According to the first, genealogical concept, Enlightenment is a bewildered form of self-preservation that has existed since the dawn of Western civilization. The second, critical historicist concept views Enlightenment as the critical and anti-authoritarian ideals articulated - most radically in eighteenth-century France - during the uneven development of modern bourgeois society. After examining the origins of these two concepts in Adorno and Horkheimer's early writings, the article demonstrates why the former became dominant in Dialectic of Enlightenment, while at the same time pointing to significant traces of the latter that remained. The article contends that a reconsideration of the latter concept reveals of a model of early Critical Theory that can still provide a compelling alternative not only to Dialectic of Enlightenment, but also more recent attempts to place Critical Theory on normative foundations.

Keywords: Enlightenment; historicism; Max Horkheimer; Theodor Adorno; Frankfurt School.

DOI: https://doi.org/10.1086/688404

$\mathrm{Na}$ visão atualmente dominante da história da Teoria Crítica, a Dialética do Esclarecimento é normalmente considerada a magnum opus da "primeira geração" da "Escola de Frankfurt". Entre os muitos problemas associados a essa percepção, ela

* A versão em inglês deste artigo foi publicada em Critical Historical Studies (ISSN 2326-4462), 3(2), Fall 2016, pp.283-308. https://doi.org/10.1086/688404. ( ) 2016 by The University of Chicago. Tradução de Simone Fernandes. 
obscurece não apenas diferenças importantes que existiram entre Max Horkheimer e Theodor Adorno no fim dos anos 1920 e nos anos 1930, como também mudanças decisivas que ocorreram na conceitualização geral da Teoria Crítica entre os anos 1930 e 1940. A seguir, examinarei as diferenças entre os conceitos de Esclarecimento de Horkheimer e Adorno nos anos 1930 e como elas foram parcialmente dissipadas na Dialética do Esclarecimento, com Horkheimer se aproximando da posição da Adorno. ${ }^{1}$ Após prover uma breve visão geral da interpretação de Horkheimer do Esclarecimento histórico, examinarei o novo conceito de Esclarecimento que Horkheimer e Adorno introduzem na Dialética do Esclarecimento. Em contraste com escritos anteriores de Horkheimer, nos quais enfatizara o caráter crítico e antiautoritário do Esclarecimento histórico - especialmente na França -, na Dialética do Esclarecimento, Horkheimer e Adorno enfatizam os aspectos repressivos e até mesmo "totalitários" do Esclarecimento, que agora veem como uma forma de racionalidade burguesa característica da civilização ocidental como um todo. Embora este novo conceito seja dominante na Dialética do Esclarecimento, também gostaria de demonstrar que traços significativos do conceito inicial de Horkheimer podem ser encontrados no texto. Como veremos, Horkheimer e Adorno consideravam a Dialética do Esclarecimento um primeiro passo rumo a um projeto maior de preparar fundações para um conceito mais positivo e genuinamente crítico e emancipatório de Esclarecimento, mas nunca completaram este projeto. Gostaria de sugerir que, para aqueles interessados em se basearem nos esforços consideráveis de Horkheimer e Adorno para desenvolver um conceito emancipatório de Esclarecimento e uma Teoria Crítica da dominação social nas sociedades modernas capitalistas, uma reconsideração do modelo historicista crítico de Esclarecimento encontrado nos trabalhos iniciais de Horkheimer oferece um ponto de partida mais promissor do que o conceito genealógico de Esclarecimento que se move para o centro de seus escritos no início dos anos $1940 .^{2}$

1 Este artigo representa uma tentativa de desenvolver uma interpretação da Dialética do Esclarecimento
à qual aludi na conclusão de meu livro Max Horkheimer and the Foundations of the Frankfurt School
(Abromeit, 2011, pp.425-432) - doravante MHFFS.

2 Na introdução de On Max Horkheimer: New Perspectives - uma coletânea de ensaios que coeditaram para a MIT Press em 1993 - Seyla Benhabib, Wolfgang Bonss e John McCole afirmaram: "Em vista do papel de Horkheimer como fundador da teoria crítica, é surpreendente que seu trabalho seja tão pouco conhecido e estudado. Em comparação com a proliferação de estudos sobre Marcuse, Adorno e Benjamin, Horkheimer tem sido relativamente negligenciado na literatura acadêmica" (Benhabib, Bonss, McCole, 1993, p.10). Eles apresentam seu próprio livro - que incluiu ensaios de eruditos e estudiosos de Horkheimer tais como Jürgen Habermas, Alfred Schmidt, Axel Honneth, Martin Jay e Moishe Postone - como uma contribuição para uma "reavaliação emergente do trabalho de Horkheimer" (idem, p.12). Ao mesmo tempo, Benhabib, Bonss e McCole posicionaram a versão particular de Horkheimer da Teoria Crítica, desenvolvida em seus escritos dos anos 1930, como que antecipando e tendo sido levada adiante por Jürgen Habermas, em seus esforços de situar a Teoria Crítica em fundamentos normativos e refunda-la nas ciências sociais (idem, pp.11-12). Neste artigo e em meu livro sobre Horkheimer (MHFFS, citado na nota 1), que também pretendem encorajar uma reavaliação da primeira Teoria Crítica de Horkheimer, tomo um caminho diferente de Benhabib et al. Embora eu destaque as afinidades entre a primeira Teoria Crítica de Horkheimer e os primeiros trabalhos de Habermas (especialmente seu estudo Mudança estrutural na esfera 


\section{O conceito historicista crítico de Esclarecimento nos primeiros trabalhos de Horkheimer}

Inicialmente examinemos brevemente a interpretação do Esclarecimento histórico dos primeiros escritos de Horkheimer. A seguir, irei basear-me principalmente em uma série de aulas sobre a história da filosofia moderna que Horkheimer proferiu em fins dos anos 1920, ${ }^{3}$ cujo modelo de Esclarecimento permaneceu relativamente constante até fins dos anos 1930 (cf. MHFFS, pp.101-111,410-413). Enquanto alguns estudiosos enfatizaram a unidade geral do Esclarecimento (cf. Gay, 1966, 1969), o primeiro Horkheimer enfatiza o caráter distinto que este possuiu em diferentes contextos nacionais. Ele reporta estas diferenças ao desenvolvimento irregular da sociedade burguesa na Inglaterra, na França e na Europa Central germânica (MHGS, 9, pp.346-400). Horkheimer sustenta que o Esclarecimento alcançou sua forma paradigmática na França devido à particular constelação de forças sociais, econômicas e políticas ali operantes. Em contraste com a Inglaterra, que já havia levado a cabo uma revolução política burguesa em 1688 e estava a caminho de estabelecer uma

pública: investigações sobre uma categoria da sociedade burguesa, primeiramente publicado em 1962), acredito que Habermas abandonou este modelo entre meados e fins dos anos 1960, quando começou a preparar as bases para sua posterior e monumental Teoria da ação comunicativa. Como indicado no subtítulo, o livro Mudança estrutural era uma "investigação sobre uma categoria da sociedade burguesa", que vinculava a indicativa transformação da função crítico-revolucionária da esfera pública à posição política e social crescentemente conservadora da burguesia no século XIX. Também prestou particular atenção às formas pelas quais o desenvolvimento irregular da sociedade burguesa, na Inglaterra, na França e na Alemanha, influenciou o desenvolvimento e a transformação da esfera pública. Como exponho neste artigo, há uma abordagem similar nas primeiras interpretações de Horkheimer do Esclarecimento histórico - e também em muitos de seus ensaios dos anos 1930. Mas, como expôs John P. McCormick (2007, pp.43-69), após o livro sobre a esfera pública houve uma mudança substancial na teoria da história de Habermas, de um foco sobre o desenvolvimento e a transformação irregulares da sociedade burguesa no capitalismo moderno para uma maior ênfase sobre a mudança qualitativa das sociedades pré-modernas para as "modernas". Enquanto os primeiros trabalhos de Habermas, até (e inclusive) o livro sobre a esfera pública, estavam ainda firmemente ancorados em um marxismo hegeliano crítico bastante similar àquele do primeiro Horkheimer, Habermas voltou cada vez mais seus esforços - de meados dos anos 1960 em diante - para situar a Teoria Crítica em fundamentos normativos e para recuperar os fundamentos filosóficos das sociedades liberais-democráticas modernas. Habermas deslocou-se cada vez mais de uma crítica das novas formas de dominação social que emergiram no capitalismo moderno para uma teoria evolutiva e para a defesa do conteúdo positivo da "modernidade" como a diferenciação das esferas de valor. Esta mudança pode também explicar porque o livro de Habermas sobre a esfera pública foi tão bem recebido pelos historiadores (veja-se, por exemplo, Habermas and the Public Sphere [Calhoun,1992]), ao passo que seu trabalho posterior tem sido amplamente ignorado por estes. Em suma, considero que a primeira Teoria Crítica de Horkheimer fornece uma alternativa não apenas para a Dialética do Esclarecimento, mas também para a teoria de Habermas depois de diversas "viradas" filosóficas - normativa, linguística, pragmática e procedimental - entre meados e fins dos anos 1960, que o afastaram dos pressupostos Teórico-Críticos que marcavam seu trabalho inicial.

3 Estas aulas foram publicadas em Horkheimer, M. (1987). Gesammelte Schriften, vols. 9-10. Alfred Schmidt and Gunzelin Schmid Noerr (eds.). Frankfurt: Fischer. (Doravante citadas como MHGS). As aulas aqui discutidas foram proferidas por Horkheimer na universidade Johann Wolfgang Goethe em Frankfurt durante o semestre de verão de 1927. 
sociedade de mercado moderna durante o século XVIII, o desenvolvimento das instituições políticas burguesas estava atrasado na França. Isto ocorreu em medida ainda maior nos principados fragmentados da Europa Central germânica. Uma vez que a sociedade burguesa já havia começado a estabelecer seu domínio na Inglaterra no decorrer do século XVII, o pensamento Esclarecido do século XVIII deste país não apresentava as tendências políticas acentuadas e frequentemente radicais que caracterizam o Esclarecimento francês. Horkheimer aponta o caráter afirmativo da economia política britânica e o ceticismo resignado de David Hume como sintomas de uma sociedade burguesa já bem estabelecida na Inglaterra (cf. MHGS, 9, pp.445,456-457). O relativo atraso econômico e político da Alemanha, em contraste, manifestou-se filosoficamente, de acordo com Horkheimer, na inabalável importância da teologia e da metafísica - como nos esforços de Kant em resgatar uma metafísica da moralidade (cf. MHGS, 9, pp.346-353; 10, pp.24-63). A sociedade burguesa havia feito avanços significativos na França no século XVIII, mas ainda era controlada por uma poderosa aristocracia e monarquia absoluta. Como resultado destas relações sociais historicamente específicas, a filosofia do Esclarecimento assumiu uma forma decisivamente política e frequentemente radical na França (cf. MHGS, 9, pp.353-391). De acordo com Horkheimer, os princípios críticos e tendencialmente materialistas dos philosophes eram não apenas uma expressão da sociedade burguesa ascendente na França, mas também apontavam para além dela e antecipavam muitos ideais socialistas do século XIX.

Para preparar o cenário para uma comparação com o modelo de Esclarecimento encontrado posteriormente na Dialética do Esclarecimento, examinemos brevemente algumas das características definidoras do Esclarecimento francês, que é paradigmático para o conceito de Esclarecimento como um todo nos trabalhos iniciais de Horkheimer. Ele enfatiza o caráter não-absoluto e materialista dos conceitos de razão e verdade dos philosophes, desenvolvidos como crítica aos construtores de sistemas idealistas da metafísica racionalista do século XVII (MHGS, 9, pp.352-353). ${ }^{4}$ Inspirando-se na crítica de Locke às ideias inatas, os philosophes desenvolveram e radicalizaram sua epistemologia sensualista, que serviu de base para seu conceito materialista de razão. De acordo com essa concepção, a consciência estava sempre fundamentada e dependente de seu outro, seja a natureza ou a história humana e a sociedade. A razão e a busca pela verdade não eram valorizadas como um fim em si mesmas, como para os racionalistas do século XVII a exemplo de Descartes e Leibniz, mas enquanto meios para atingir a felicidade humana. Em contraste com os conceitos metafísicos totalizantes e abstratos dos racionalistas, os philosophes

\footnotetext{
4 Neste ponto, Horkheimer está de acordo com Peter Gay, que afirma que "a glorificação da crítica [dos philosophes] e seu repúdio qualificado da metafísica evidenciam que o Esclarecimento não constitui uma Era da Razão, mas uma revolta contra o racionalismo" (Gay, 1966, p.141). Acerca do conceito antimetafísico e antiabsoluto de verdade do Esclarecimento, veja-se Bates, 2002.
} 
insistiam para que a razão fosse fundada na experiência e utilizada para enfrentar problemas contemporâneos. Ao mesmo tempo, o conceito de razão do Esclarecimento francês não era puramente subjetivo ou pragmático, na medida em que era guiado por ideais políticos substantivos, como justiça, igualdade e humanismo. Por exemplo, os philosophes interpretaram o argumento de Locke de que todos os seres humanos nascem como uma tabula rasa como uma crítica universalista ao sistema estatal hierárquico na França. Os philosophes tiraram consequências políticas dos argumentos epistemológicos abstratos de Locke. Como sociólogos do conhecimento do século XX, enfatizaram os fatores completamente contingentes e sociais que criam distinções de classe e status. Uma vez que tais condições eram criadas por seres humanos, poderiam também ser modificadas. Horkheimer enfatiza, em particular, a crítica dos philosophes ao autoritarismo e ao preconceito, que caminhavam juntos. De acordo com os materialistas mais radicais entre os philosophes, como Holbach and Helvetius, “os governantes acreditam que é de seu interesse manter as opiniões predominantes; os preconceitos e erros que eles consideram necessários para garantir o seu poder são mantidos com uma violência que nunca é razoável” (MHGS, 9, p.374). Os philosophes consideravam a disseminação de tais visões críticas como uma tentativa ativa de modificar não apenas o modo como as pessoas pensavam, mas também as condições sociais e políticas em que viviam. O importante vínculo causal entre o Esclarecimento francês e a Revolução Francesa, reconhecido por Hegel e muitos outros, deixa claro que os seus esforços intelectuais tiveram consequências práticas.

Em suma, Horkheimer desenvolveu um modelo de Esclarecimento em fins dos anos 1920 e até meados da década de 1930 que era robustamente crítico e baseado em uma história da filosofia ocidental moderna amplamente materialista, como uma expressão mediada do desenvolvimento irregular da sociedade burguesa. Em outros escritos deste período, Horkheimer demonstrou como os ideais críticos e utópicos do Esclarecimento francês e do Esclarecimento em geral seriam gradualmente esvaziados e colocados a serviço do status quo após o triunfo da burguesia e sua resposta ao desafio do novo movimento socialista no século XIX. Ainda assim, no contexto das correntes de pensamento nacionalistas e irracionalistas crescentemente poderosas nos últimos anos da República de Weimar, Horkheimer considerou importante recuperar os ideais críticos e universalistas do Esclarecimento francês. Em comparação a muitos de seus contemporâneos de esquerda, como Ernst Bloch, Walter Benjamin e Herbert Marcuse, Horkheimer estava mais preocupado com a facilidade com que tais correntes antirracionalistas, como a fenomenologia e o vitalismo, poderiam ser colocadas a serviço de um projeto político conservador revolucionário, como seriam por Martin Heidegger, Carl Schmitt, Hans Freyer e outros. ${ }^{5}$ Seus esforços para recuperar as

5 Para um exame mais detalhado das diferenças de Horkheimer em relação a outros marxistas ocidentais quanto às poderosas correntes antirracionalistas na vida intelectual e cultural de Weimar, 
dimensões críticas e antiautoritárias do Esclarecimento francês também devem ser vistos como uma resposta a esta constelação particular, à qual pertenciam também apelos chauvinistas à Kultur alemã como sendo superior ao alegadamente superficial racionalismo da Inglaterra e da França e à civilisation. ${ }^{6}$ Apesar da influência inegável que os debates intelectuais de Weimar tiveram sobre o conceito de Esclarecimento de Horkheimer neste período, ele também transcende este contexto na medida em que situa o Esclarecimento diretamente dentro do desenvolvimento mais amplo e historicamente específico da sociedade burguesa. Com esta abordagem historicista crítica, Horkheimer está atento à forma e à função cambiantes das ideias não apenas em diferentes estágios da sociedade burguesa, mas também em diferentes contextos nacionais.

No início dos anos 1940, quando Horkheimer e Adorno começaram a trabalhar seriamente na Dialética do Esclarecimento, o contexto em que viviam e escreviam era dramaticamente diferente. Horkheimer estava nos Estados Unidos desde 1934. Adorno havia se realocado de Oxford para Nova York em 1938, antes de se mudar com Horkheimer para o sul da Califórnia em 1941. A seguir, gostaria de argumentar que há uma tensão na Dialética do Esclarecimento entre um conceito dominante de Esclarecimento como uma noção desistoricizada de razão instrumental e dominação da natureza, por um lado, e um conceito historicizado de Esclarecimento como expressão mediada da transformação da sociedade burguesa, por outro lado. 0 primeiro conceito pode ser imputado principalmente a Adorno, mas também a escritos de Walter Benjamin dos anos 1920 e 1930. Já vimos as origens do segundo conceito nos primeiros escritos de Horkheimer. O predomínio do novo conceito desistoricizado de Esclarecimento como razão instrumental pode ser parcialmente explicado em termos da já mencionada mudança no contexto intelectual e social, que aparentemente teve maior impacto sobre o pensamento de Horkheimer do que sobre Adorno. Enquanto Horkheimer havia considerado as poderosas correntes antirracionalistas de pensamento - especialmente em suas formas popularizadas - como a ameaça mais séria no contexto da Alemanha de Weimar, após sua chegada aos Estados Unidos ele veio a considerar o crescente predomínio de um positivismo irrefletido, que tinha raízes profundas nas tradições intelectuais anglo-americanas e foi reforçado pelos recém imigrados da Escola de Viena, como a maior ameaça ao pensamento crítico. Por sua vez, Adorno sempre havia sido menos simpático à tradição empirista na filosofia, ${ }^{7}$

veja-se "The Vicissitudes of the Politics of 'Life': Herbert Marcuse and Max Horkheimer's Reception of Phenomenology and Vitalism in Weimar Germany" - Abromeit, 2006.

6 Para uma análise das origens sociohistóricas desta distinção entre a Kultur alemã e a civilização britânica-francesa que figurou proeminentemente no arsenal ideológico da Alemanha Imperial, veja-se $O$ processo civilizador (Elias,1982).

7 Para um exemplo interessante e sintomático de como Horkheimer inicialmente discordava de Adorno sobre o empirismo filosófico, veja-se a discussão entre eles em novembro de 1931 sobre o papel das impressões sensoriais em uma teoria do conhecimento e da sociedade. Simplificando um pouco, a 
e, por isso, sua imigração para os Estados Unidos apenas reforçou tais tendências em seu pensamento. ${ }^{8} \mathrm{O}$ ensaio de Horkheimer de 1937, "O mais recente ataque à metafísica”, em que desenvolve uma crítica contundente ao positivismo lógico, pode ser considerado o início de um movimento que o aproximaria da interpretação de Adorno, mais integralmente crítica da tradição empirista. ${ }^{9}$ No entanto, mesmo neste ensaio, Horkheimer situa a ascensão do positivismo no contexto mais amplo de transformação da sociedade burguesa; ele ainda interpreta as tendências empiristas

discordância principal reside na defesa de Horkheimer das impressões sensoriais como uma forma essencial de evidência, enquanto Adorno insiste que as impressões sensoriais são sempre constituídas subjetivamente e socialmente e, portanto, não possuem nenhuma pretensão de validade autônoma. Cf. MHGS, 12, pp.367-372.

8 Adorno sentiu um choque inicial após realocar-se para os Estados Unidos em 1938 e ser confrontado com as atitudes positivistas dominantes, o que se expressou, entre outros acontecimentos, em sua rejeição do esforço de Paul Lazarsfeld em "quantificar a cultura" no Princeton Radio Research Project, mas também nos contundentes ataques ao positivismo na Dialética do Esclarecimento. Não muito tempo depois, no entanto, Adorno desenvolveu um maior apreço pelo valor da pesquisa empírica social - especialmente quando embasada em uma teoria freudo-marxista da sociedade - e, portanto, aparentemente, se aproximou até certo ponto do modelo de Teoria Crítica de Horkheimer nos anos 1930. Acerca das atitudes cambiantes de Adorno a respeito do empirismo e da pesquisa social empírica durante o seu exílio nos Estados Unidos, veja-se Jenemann, 2007, pp.1-47; Wheatland, 2009, pp.191-263; e as próprias memórias de Adorno (1998, pp.215-244). Sobre a crescente tendência ao positivismo na vida intelectual dos Estados Unidos nos anos 1940, veja-se Schorske, Bender, 1997.

9 A visão crescentemente crítica de Horkheimer em relação à tradição filosófica empírica foi apenas um dos pontos em que se aproximou de muitas das posições teóricas de Adorno por volta de 1940 . Em contraste com Adorno, Horkheimer havia sustentado ao longo dos anos 1930 que a Teoria Crítica pode e deve apoiar-se nas "ciências tradicionais", mas no prefácio da Dialética do Esclarecimento ele e Adorno declararam categoricamente que "tivemos de abandonar aquela confiança". Enquanto Adorno apoiava-se fortemente no conceito de reificação de Georg Lukács nos anos 1930, Horkheimer o criticava, e não se pode encontrar vestígios deste conceito em seus escritos dos anos 1930. Mas, pouco depois de intensificar sua colaboração intelectual com Adorno, Horkheimer começou a defender o conceito de reificação tão enfaticamente quanto ele, como na seguinte passagem de uma carta que escreveu para Hans Meyer em março de 1939: "a categoria da mercadoria é aquela que ilumina a sociedade inteira como um refletor (...) Este aspecto da teoria de Marx é em seus detalhes mais íntimos idêntico à crítica da reificação e eu não penso que seria difícil demonstrar que o capital é dominado mesmo em seus menores aspectos econômicos pela teoria da reificação" (MHGS, 16, pp.576). Nos anos 1930, Horkheimer e Adorno também discordaram acerca da relação entre dialética e historicismo e especialmente sobre as implicações epistemológicas desta relação. Enquanto Horkheimer interpretava a filosofia moderna como uma expressão mediada do desenvolvimento irregular da moderna sociedade burguesa, Adorno contrapunha que "a verdade não está na história", mas em vez disso a "história está na verdade" (citado em MHFFS, p.384). Com isso, Adorno quis dizer que o conteúdo de verdade histórico da filosofia - e das obras de arte autônomas - poderiam apenas ser apreendidos por meio de cuidadosa imersão em seus detalhes particulares e nunca ao se subsumir esses particulares sob amplos conceitos de períodos históricos. Aqui, talvez, foi onde a influência do primeiro Benjamin - com sua insistência no primado epistemológico do particular e sua rejeição de conceitos de períodos históricos em estética - foi mais evidente sobre Adorno. Em seu prefácio de 1936 aos Estudos sobre autoridade e família, Horkheimer defendeu explicitamente o conceito de época histórica e sua necessidade para uma Teoria Crítica da sociedade moderna (cf. MHGS, 3, pp.336-42). Mas, como o conceito trans-epocal de Esclarecimento que ele e Adorno adotaram no começo dos anos 1940 evidenciou, Horkheimer havia se aproximado de Adorno também neste ponto. Para uma discussão minuciosa da divergência teórica e da eventual aproximação entre Horkheimer e Adorno no decorrer dos anos 1930, veja-se MHFFS, pp.349-393. 
“protopositivistas" no início do período moderno como levando adiante a causa da liberdade intelectual e da racionalidade contra as tradições ossificadas da teologia católica e da metafísica racionalista.

$\mathrm{Na}$ Dialética do Esclarecimento, Horkheimer e Adorno apresentam este problema de modo bastante diferente. Eles agora consideram a transformação supostamente contínua do Esclarecimento do século XVIII em positivismo como um forte indicador da falta de autorreflexibilidade que havia caracterizado desde o início o conceito ocidental dominante de Esclarecimento. Esta nova convicção também embasa um dos propósitos mais básicos da Dialética do Esclarecimento. A crítica intransigente de Horkheimer e Adorno deste conceito viciado de Esclarecimento pretende restaurar sua perda de autorreflexividade e, ao fazê-lo, "preparar um conceito positivo de Esclarecimento, que o solte do emaranhado que o prende a uma dominação cega" (DoE, p.xviii [15]) ${ }^{10}$. Em 1946, cogitaram brevemente a possibilidade de escrever um volume associado à Dialética do Esclarecimento, de modo a resgatar um conceito positivo de Esclarecimento, mas o projeto nunca foi levado adiante (MHGS, 12, pp.593-605). Uma das questões que gostaria de propor neste artigo é se o conceito de Esclarecimento dos primeiros trabalhos de Horkheimer - cujos resquícios ainda podem ser encontrados na Dialética do Esclarecimento - poderia fornecer uma base para os esforços atuais de Teóricos Críticos no desenvolvimento de um tal "conceito positivo de Esclarecimento". ${ }^{11}$ Não é uma questão que pode ser

10 Horkheimer, M. and Adorno, T. W. (2002). Dialectic of Enlightenment: Philosophical Fragments. Edited by. Gunzelin Schmid Noerr and translated by Edmund Jephcott. Stanford, CA: Stanford University Press, pp.xviii. Doravante citada como DoE, com a paginação da tradução brasileira de Guido Antonio de Almeida, aqui utilizada, entre colchetes.

11 Retomando algumas das questões abordadas acima (nas notas 2 e 7), vale enfatizar novamente que o conceito de Esclarecimento encontrado nos primeiros trabalhos de Horkheimer baseia-se em uma abordagem macro-histórica para compreender a "modernidade" como a ascensão do capitalismo moderno, o concomitante desenvolvimento irregular e a subsequente transformação da sociedade burguesa. Talvez não seja coincidência que os trabalhos de Walter Benjamin e - em menor medida - de Theodor Adorno tenham desfrutado de maior atenção acadêmica durante os anos 1980 e 1990, quando críticas pós-modernas das "grandes narrativas" e uma mais ampla mudança epistemológica do geral para o particular podiam ser observadas na história e em outras disciplinas acadêmicas. Mas, por volta da década passada, abordagens macro-históricas, em geral, e um renovado foco sobre a história do capitalismo, em particular, tiveram um forte retorno. Por exemplo, William Sewell, que foi um dos primeiros advogados da virada "cultural" na história, análoga e influenciada pela crescente influência das teoria pós-moderna e pós-estruturalista na academia estadunidense nos anos 1970 e 1980, recentemente afirmou que o "defeito comum" do revisionismo histórico dos anos 1980 e 1990 foi o seu "recuo da macrocausa em geral e da consideração da dinâmica do capitalismo em particular (...) no momento em que a dinâmica do capitalismo demonstrou uma renovada habilidade de perturbar profundamente e reconfigurar fundamentalmente nossas próprias vidas sociais, políticas e culturais" (Sewell, 2005, p.77). Ao mesmo tempo, no entanto, Sewell argumenta que não deveríamos retornar para a abordagem quantitativa unidimensional dos historiadores sociais dos anos 1960. Hoje, os historiadores precisam desenvolver ferramentas conceituais que lhes permitirão falar de causas sociais de larga escala, mas também permanecerem sensíveis aos modos como questões de cultura e significado influenciam decisivamente processos e eventos históricos. Sustento que o trabalho inicial de Horkheimer nos provê exatamente um tal modelo: toma como ponto de partida as forças macrohistóricas que emergem - e ainda permanecem - na época burguesa moderna, mas também leva 
investigada aqui se a compreensão de Adorno acerca do Esclarecimento em geral ou do Esclarecimento histórico, em particular, modificou-se ou não em seus escritos posteriores - por exemplo, com uma tentativa de reconceitualizar a noção de autonomia de Kant. ${ }^{12}$ A seguir, colocarei em foco os dois conceitos de Esclarecimento que coexistem em tensão na Dialética do Esclarecimento.

\section{O novo conceito genealógico de Esclarecimento na Dialética do Esclarecimento}

Para demonstrar a tensão entre os dois modelos de Esclarecimento acima mencionados na Dialética do Esclarecimento, examinemos primeiramente algumas das formas principais pelas quais o novo e dominante conceito de Esclarecimento é determinado. No capítulo inicial do estudo, que é explicitamente dedicado ao desenvolvimento deste novo "Conceito de Esclarecimento", Horkheimer e Adorno descrevem o Esclarecimento das seguintes formas: "submissão de tudo aquilo que é natural ao sujeito autocrático" (DoE, p.xviii [15]); “o Esclarecimento é a radicalização da angústia mítica” (DoE, p.11 [26]); “o que não se submete ao critério da calculabilidade e da utilidade torna-se suspeito para o Esclarecimento" (DoE, p.3 [19]); "a técnica é a essência desse saber" (DoE, p.2 [18]); “o Esclarecimento é totalitário" (DoE, p.4 [19]). Em contraste com o conceito anterior de Esclarecimento de Horkheimer, que tomou as tendências críticas e antiautoritárias dos philosophes como modelo, o novo conceito de Horkheimer eAdorno coloca foco fundamentalmente sobre o triunfo de uma forma de razão subjetiva tendencialmente "totalitária", que encontra a sua mais pura expressão no positivismo lógico do século XX, mas cujo princípio subjacente de "autopreservação" é revelado como "a verdadeira máxima de toda a civilização ocidental” (DoE, p.22 [36]). Marx uma vez afirmou que "a anatomia dos humanos contém a chave para a anatomia dos macacos", no sentido de que elementos latentes do futuro que existem no passado podem ser reconhecidos apenas sob o ponto de vista de uma compreensão autorreflexiva da época histórica atual. Por um lado, parece que Horkheimer e Adorno seguem Marx em sua asserção de que as formas de Esclarecimento atuais "mais avançadas" - como o positivismo lógico - contêm uma chave para o Esclarecimento como um todo. Eles escrevem, por exemplo, que “muito antes de Turgot e d'Alembert, a forma burguesa do Esclarecimento já se perdera em seu aspecto positivista” (DoE, p.32 [44]). Por outro lado, gostaria de argumentar aqui que Horkheimer e Adorno são menos

a sério a relativa autonomia da cultura - tanto em seu sentido antropológico mais amplo como em seu mais estreito significado, referindo-se a trabalhos intelectuais e artísticos. Para uma discussão da compreensão de Horkheimer da relativa autonomia da cultura, veja-se "Max Horkheimer et le concept matérialiste de la culture" - Abromeit, 2013, pp.53-70.

$12 \mathrm{Em}$ seu substancial e envolvente estudo recente, Autonomy after Auschwitz: Adorno, German Idealism, and Modernity, Martin Schuster (2014) interpreta desta maneira os trabalhos de Adorno do pós-guerra. 
bem-sucedidos do que Marx ao atribuírem uma significância causal muito maior às supostas "origens" da forma viciada de Esclarecimento que se tornou aparente de seu ponto de vista atual. Enquanto o método de Marx permanece histórico crítico, em sua insistência de que o desenvolvimento de potencialidades latentes em formas arcaicas historicamente - como a mercadoria - é determinado por relações sociais na época história contemporânea, o conceito trans-histórico de Esclarecimento de Horkheimer e Adorno explica acontecimentos do presente em termos de suas origens arcaicas, projetando, deste modo, relações burguesas em épocas históricas precedentes. A oposição de Marx a uma tal abordagem é clara, caso se examine o contexto mais amplo da famosa frase acima citada:

a anatomia dos humanos contém a chave para a anatomia dos macacos. Os indícios de uma forma superior nas espécies animais inferiores, no entanto, só podem ser compreendidos depois que o desenvolvimento superior já é conhecido. A economia burguesa, deste modo, fornece a chave para a antiga, etc. Mas de modo algum à maneira daqueles economistas que borram todas as diferenças históricas e veem relações burguesas em todas as formas de sociedade (Marx, 1978, p.241, grifos meus).

Em suma, Marx enfatiza nossa habilidade de reinterpretar o passado à luz dos acontecimentos do presente, sem insistir que o passado arcaico determina o presente de maneira teleológica. ${ }^{13}$

Um olhar lateral para as diferenças entre os métodos de Nietzsche e Heidegger também pode ser útil para especificar a maneira como estou utilizando o conceito de genealogia aqui. Nietzsche critica a busca por origens causais no passado antigo e concentra-se, em vez disso, nas maneiras múltiplas e imprevisíveis pelas quais o significado de conceitos - tais como moral - são transformados por acontecimentos históricos mais recentes. O significado e a função social de algo como a "moralidade" em diferentes épocas históricas não tem nenhum poder teleológico sobre o seu significado no presente (cf. Nietzsche, 1969, pp.76-79). Heidegger, em contraste, atribui os principais vícios da racionalidade ocidental ao esquecimento da questão do significado do ser, que ocorreu na passagem dos filósofos pré-socráticos para Sócrates e Platão e na tradução de conceitos filosóficos gregos para o latim. Embora certamente o conteúdo do argumento de Horkheimer e Adorno seja diferente do de Heidegger, seus esforços em identificar as origens arcaicas dos vícios fundamentais do Esclarecimento moderno e a sua asserção de que a civilização ocidental como um

13 Embora não esteja de acordo com todos os aspectos da interpretação de Moishe Postone acerca dos primeiros trabalhos de Horkheimer, concordo com sua ênfase no caráter plenamente histórico e autorreflexivo dos conceitos de Marx e considero esta ênfase totalmente compatível com o primeiro modelo de Teoria Crítica de Horkheimer. Para a crítica de Postone sobre Horkheimer, veja-se Tempo, trabalho e dominação social: uma reinterpretação da teoria crítica de Marx (Postone, 1993, pp.104-120). Para minha tentativa de demonstrar porque a primeira Teoria Crítica de Horkheimer e os conceitos dialéticos em que se baseia são plenamente históricos e autorreflexivos, veja-se MHFSS, pp.301-335. Para uma discussão mais detalhada e uma réplica à crítica de Postone aos primeiros trabalhados de Horkheimer, veja-se MHFSS, pp.420-424. 
todo está dominada por este conceito de racionalidade fundamentalmente vicioso e relativamente constante, cujas origens estabelecem os padrões - ou ao menos os limites - de todos os desenvolvimentos subsequentes, têm de fato uma semelhança notável com Heidegger. É nesse sentido em particular que gostaria de descrever a abordagem teórica subjacente ao novo conceito de Esclarecimento de Horkheimer e Adorno como "genealógica": eles buscam compreender uma ampla variedade de precedentes históricos e histórico-intelectuais que exibem sinais reveladores de um conceito inadequado de Esclarecimento que estava predestinado a autodestruir-se desde o início. Enquanto Marx e Nietzsche reconhecem que ganhamos novos insights sobre o passado com base em nosso conhecimento do presente, eles não explicam o presente como pré-determinado por estes fatores passados. Os fatores causais que determinam o presente são buscados em acontecimentos históricos mais recentes, como também é o caso na abordagem historicista crítica do primeiro Horkheimer.

Até agora, vimos Horkheimer e Adorno descreverem o Esclarecimento em termos da dominação da razão subjetiva sobre a natureza externa, da redução do pensamento a fórmulas matemáticas e à probabilidade, um espirit du systeme tendencialmente totalitário, e da perda de autorreflexibilidade inerente a uma forma confusa de autopreservação que sacrifica seu próprio self. A esta lista pode-se acrescentar a dominação da natureza interna e o desenvolvimento de métodos sistemáticos para dominar os outros; uma filosofia da história baseada em uma compulsão para reproduzir categorias e condições existentes, que barra a possibilidade de quaisquer experiências qualitativamente novas; a celebração de uma noção idealista de autonomia absoluta que permanece cega às condições de heteronomia que a tornam possível; a secularização do sacrifício mítico por meio de sua transformação de um ritual externo em um dever internalizado; e, finalmente, o triunfo dos meios sobre os fins - como exemplificado positivamente pelo conceito de Max Weber de Zweckrationalität (racionalidade de meios e fins) e criticamente pelo conceito de Marx de capital. Nota-se de imediato que muitas das características definidoras deste conceito negativo de Esclarecimento estão em clara oposição às características do Esclarecimento encontradas na determinação inicial do conceito por Horkheimer. Mas, antes de observarmos mais de perto esta contradição, examinemos a Dialética do Esclarecimento para verificar por que e em que sentido seu conceito dominante de Esclarecimento é trans-histórico.

Não surpreendentemente, as tendências trans-históricas na Dialética do Esclarecimento emergem mais claramente no primeiro excurso sobre a Odisseia de Homero, que estudiosos hoje sabem que foi concebido e escrito principalmente por Adorno. ${ }^{14} \mathrm{Em}$ debates com Horkheimer no fim dos anos 1930, Adorno já havia defendido a tese principal de que "o mito já é Esclarecimento e o Esclarecimento

14 Veja-se o “Editor's Afterword” de Gunzelin Schmid Noerr (DoE, pp.219-224). 
reverte à mitologia" (DoE, p.xviii [15]), elaborado no excurso sobre a Odisseia. Nesses debates, Adorno expressou repetidamente reservas em relação aos métodos historicistas que acreditou terem embasado muitos dos ensaios publicados por Herbert Marcuse e pelo próprio Horkheimer na Zeitschrift für Sozialforschung, tais como "Sobre o caráter afirmativo da cultura" e "Sobre o conceito de essência", de Marcuse, e nos ensaios de Horkheimer "O mais recente ataque à metafísica" e "Montaigne e a função do ceticismo". ${ }^{15}$ Estes ensaios analisaram transformações de conceitos filosóficos e culturais burgueses fundamentais no contexto mais amplo de uma "dialética da sociedade burguesa" no período moderno. ${ }^{16}$ Contra os esforços de Marcuse e Horkheimer para demonstrar como o conteúdo de conceitos burgueses mudou e como a sua função crítica foi minada no século XIX, Adorno enfatizou "quão pouco em princípio o pensamento burguês modificou-se". ${ }^{17}$ Influenciado pelas reflexões de Benjamin sobre a persistência do mito na modernidade, Adorno argumentou que as formas "burguesas" de pensamento estiveram em estado nascente nos primeiros documentos da civilização humana e que a sociedade burguesa moderna permaneceu presa na dinâmica fatídica da história natural. ${ }^{18}$

Tais argumentos reaparecem e são elaborados na Dialética do Esclarecimento, especialmente no excurso sobre a Odisseia. Sobre Ulisses, escreve-se: "o herói das aventuras revela-se precisamente como um protótipo do indivíduo burguês, cujo conceito tem origem naquela autoafirmação unitária que encontra seu modelo mais antigo no herói errante" (DoE, p.35 [47]) e "Ulisses vive segundo o princípio primordial que constituiu outrora a sociedade burguesa" (DoE, p.48 [59]). A astúcia de Ulisses ilustra a chave para o fracasso do Esclarecimento "burguês", que é encontrado em um conceito trans-histórico de dominação da natureza interna e externa a serviço de uma noção equivocada de autoafirmação. Eles escrevem: "A história da civilização é a história da introversão do sacrifício" (DoE, p.43 [54]) e "sua autoafirmação é, (...) como em toda civilização, uma autodenegação" (DoE, p.53 [63]). Enquanto Marx vinculou a emancipação a um esforço para a reconfiguração do relacionamento entre o reino da liberdade e o reino da necessidade, que ele compreendia como uma possibilidade objetiva em desenvolvimento no capitalismo moderno (cf. Marx, 1967,

15 Sobre a crítica de Adorno ao que ele denomina "história intelectual materialista", veja-se suas cartas a Horkheimer de 26 de maio de 1936 e 28 de outubro de 1937 - em MHGS, 15, pp.537-541 e 16, pp.264-268.

16 Sobre o conceito de uma "dialética da sociedade burguesa", veja-se MHFFS, 4, pp.394-95, pp.42932.

17 Como Adorno afirma em uma carta a Horkheimer em 26 de maio de 1936 (MHGS, 15, p.538).

18 Para análises mais detalhadas do impacto substancial de Benjamin sobre o pensamento de Adorno no fim dos anos 1920 e início dos anos 1930, de seus debates em meados dos anos 1930 e do impacto de Benjamin - especialmente de suas "Teses sobre a filosofia da história" - sobre a Dialética do Esclarecimento, veja-se: Buck-Morss, 1977, Wolin, 1994, pp.163-212 e minhas considerações em MHFFS, pp.349-74, pp.426-27. 
3, pp.818-820), o novo conceito de Esclarecimento de Horkheimer e Adorno nivela a especificidade histórica de diferentes formas de dominação social em diferentes épocas históricas e assim também obscurece as possibilidades historicamente específicas para a emancipação no presente.

Outro exemplo dos fundamentos trans-históricos deste conceito de Esclarecimento pode ser encontrado no vínculo que Horkheimer e Adorno postulam entre ele e a divisão do trabalho, que é concebida em termos trans-históricos:

Assim como as primeiras categorias representavam a tribo organizada e seu poder sobre os indivíduos, assim também a ordem lógica em seu conjunto - a dependência, o encadeamento, a extensão e união dos conceitos - baseia-se nas relações correspondentes da realidade social, da divisão do trabalho (DoE, p.16 [30]).

Na Dialética do Esclarecimento, Horkheimer e Adorno também vinculam a divisão do trabalho com a autopreservação social e individual. Escrevem: "A divisão do trabalho, em que culmina o processo social da dominação, serve à autoconservação do todo dominado" (DoE, p.16 [30]). Mas aqui novamente o conceito de autopreservação é concebido trans-historicamente:

A frase de Spinoza: "Conatus sese conservandi primum et unicum virtutis est fundamentum" contém a verdadeira máxima de toda a civilização ocidental, onde vêm se aquietar as diferenças religiosas e filosóficas da burguesia. (...) Mas quanto mais o processo da autoconservação é assegurado pela divisão burguesa do trabalho, tanto mais ele força a autoalienação dos indivíduos, que têm de se formar no corpo e na alma segundo a aparelhagem técnica. (DoE, pp.22-23 [36]).

Aqui pode-se notar claramente o contraste entre, por um lado, a ênfase de Horkheimer, nos anos 1930, sobre as diferenças importantes no conteúdo e função do pensamento burguês na época moderna, e, por outro lado, a abordagem da Dialética do Esclarecimento, em que tais diferenças "vêm se aquietar" e tudo é reduzido ao mínimo denominador comum da razão instrumental. Seria possível pensar que esta invocação da divisão burguesa do trabalho apontaria para as condições histórias específicas do capitalismo moderno, mas, como vimos, Horkheimer e Adorno agora sustentam que tais condições já existiam na antiguidade clássica, se não mais cedo. Seu argumento aqui se assemelha intimamente aos esforços de Alfred SohnRethel em vincular a emergência de categorias filosóficas idealistas à divisão do trabalho intelectual e físico na Grécia antiga. ${ }^{19}$ Mas o argumento dos autores está em contradição com a teoria madura de Marx e com a Teoria Crítica de Horkheimer nos anos 1930 , em que as formas de pensamento são fundamentadas nas relações sociais

19 Horkheimer e Adorno discordaram fortemente de meados até fins dos anos 1930 acerca do valor do trabalho de Sohn-Rhetel. Esta divergência de pontos de vista reflete suas discordâncias mais profundas acerca dos méritos de abordagem histórico-críticas versus genealógicas. Veja-se MHFFS, pp.382-288. 
de uma época histórica específica e não em uma noção abstrata e transcendente de “divisão do trabalho". ${ }^{20}$

Como outro exemplo das premissas trans-históricas atuantes na Dialética do Esclarecimento, gostaria de examinar brevemente algumas passagens que apontam para uma interpretação da história como sendo circular. Por um lado, uma interpretação circular da história não exclui a mudança, na medida em que a história progride em diferentes estágios; por outro lado, se estes mesmos estágios se repetem infinitamente, então a emergência de qualquer coisa qualitativamente nova é obstruída e, assim, a teoria permanece presa em premissas trans-históricas. Considere-se a seguinte passagem:

Nos momentos decisivos da civilização ocidental, da transição para a religião olímpica ao renascimento, à reforma e ao ateísmo burguês, todas as vezes que novos povos e camadas sociais recalcavam o mito, de maneira mais decidida, o medo da natureza não compreendida e ameaçadora (...) era degradado em superstição animista, e a dominação da natureza interna e externa tornava-se o fim absoluto da vida (DoE, p.24 [38]).

Aqui percebemos a mesma redução à equivalência de diferentes estágios na história da "civilização ocidental" - da antiguidade clássica ao presente - que caracteriza a discussão de Horkheimer e Adorno acerca da divisão do trabalho. A conexão entre a divisão do trabalho burguesa e essa concepção circular de história é também aparente na famosa discussão do encontro de Ulisses com as sereias, quando ele veda os ouvidos de seus remadores e faz-se amarrar ao mastro, para que possa apreciar sua canção. Os autores escrevem:

O servo permanece subjugado no corpo e na alma, o senhor regride. Nenhuma dominação conseguiu ainda evitar pagar esse preço, e a aparência cíclica da história em seu progresso também se explica por semelhante enfraquecimento, que é o equivalente do poderio. A humanidade, cujas habilidades e conhecimentos se diferenciam com a divisão do trabalho, é ao mesmo tempo forçada a regredir a estágios antropologicamente mais primitivos, pois a persistência da dominação determina, com a facilitação técnica da existência, a fixação do instinto através de uma repressão mais forte (DoE, pp.27-28 [40-41]).

Os argumentos de Horkheimer e Adorno aqui se aproximam perigosamente de teorias da ascensão e queda cíclicas de civilizações que eram corroboradas por

20 Em seus primeiros trabalhos, Marx também havia ocasionalmente identificado a divisão do trabalho como a fonte da dominação social. Veja-se, por exemplo, sua discussão acerca da divisão do trabalho na primeira seção de $A$ ideologia alemã (Marx, 1978, pp.158-161). Mas, em sua obra madura, ele distingue entre a divisão do trabalho na fábrica e a divisão do trabalho na sociedade. Nas sociedades capitalistas modernas, a primeira é rigidamente autoritária e a segunda é anárquica, embora Marx não considere esses vícios como inerentes à divisão do trabalho como tal, mas à forma historicamente específica das relações sociais capitalistas. Em contraste com algumas das passagens mais românticas, fourieristas, de seus primeiros trabalhos, o Marx maduro reconhece que uma divisão do trabalho avançada tanto na fábrica como na sociedade também seria necessária e benéfica para uma sociedade socialista. 
teóricos conservadores e contrarrevolucionários, de Joseph de Maistre a Vilfredo Pareto e Oswald Spengler. ${ }^{21}$ Em contraste com Hegel e Marx, que enfatizam o caráter qualitativamente novo da sociedade burguesa moderna em relação à Europa medieval e à antiguidade clássica, Horkheimer e Adorno parecem argumentar aqui que as dinâmicas de todas as "épocas desmitologizadas" são essencialmente as mesmas (DoE, p.69 [76]). ${ }^{22}$ As diferenças entre Moisés e Kant, ambos cujas "lei fria não conhece nem o amor nem a fogueira”, desaparecem em face de sua localização idêntica no ciclo repetitivo do mito e do Esclarecimento (DoE, p.89 [95]).

Como um exemplo final das tendências trans-históricas da Dialética do Esclarecimento, examinemos brevemente a discussão de Horkheimer e Adorno sobre a mimese no último capítulo, “Elementos do antissemitismo: limites do Esclarecimento", que reformula o argumento sobre o Esclarecimento como dominação da natureza em um esforço para identificar as origens arcaicas e a mais recente manipulação da "idiossincrasia" como fonte decisiva do antissemitismo. É importante notar que o uso do termo "idiossincrasia" corresponde ao significado em alemão, psicológico, de "uma aversão insuperável com relação a certas pessoas ou coisas" 23 e não ao sentido de um traço de caráter peculiar ou excêntrico. Uma importante primeira formulação desta teoria de um preconceito idiossincrático pode ser encontrada em uma carta que Adorno escreveu a Horkheimer em 18 de setembro de 1940. Ali Adorno desenvolve uma teoria especulativa da história primitiva (Urgeschichte) do antissemitismo em termos da recusa dos judeus em abandonar completamente um estilo de vida nômade e o ressentimento que esta recusa provocou nos gentios, que haviam relutantemente aceito a vida doméstica e as formas de trabalho fixas que a acompanhavam. Adorno escreve:

Uma teoria adequada do antissemitismo que vá além do pluralismo das particulares "razões para o ódio aos judeus" pode depender do desenvolvimento bem-sucedido de uma história primitiva do antissemitismo. (...) em um estado muito precoce da história da humanidade, os judeus ou rechaçaram a passagem do nomadismo à domesticidade (...) ou levaram a cabo esta transição apenas de modo incompleto e superficial. 0 conceito ocidental moderno de trabalho e toda a renúncia à gratificação instintual que o acompanha podem coincidir exatamente com o advento da domesticidade. (...) mas quanto mais o mundo da domesticidade, como um mundo de trabalho, reproduziu a repressão [repression (Unterdruckung)], tanto mais a condição antiga deve ter parecido como felicidade, que não se poderia permitir a si mesmo e cujo pensamento deveria ser proibido. Esta proibição é a origem do antissemitismo; as expulsões dos judeus foram tentativas de completar ou imitar a expulsão do paraíso

21 Horkheimer e Adorno escrevem, por exemplo: "A crítica da contrarrevolução católica provou que tinha razão contra o Esclarecimento, assim como este tinha razão contra o catolicismo" (DoE, p.71 [77-78]).

22 Eles também escrevem: "a desagregação da realidade econômica (...) tem sempre estado na base da superstição" (DoE, p.89 [94] [tradução modificada]).

23 Duden Universal Wörterbuch A-Z (Manheim: Dudenverlag, 1989), p.751 
John Abromeit

(MHGS, 16, pp.761-764)..$^{24}$

Este argumento básico reaparece em uma forma modificada na Dialética do Esclarecimento. Ali, Horkheimer e Adorno colocam maior ênfase na mimese, que é reprimida como parte de uma mais ampla dominação da natureza pela racionalidade esclarecida, que acompanha a passagem para a civilização doméstica. Esta repressão dá origem ao ressentimento idiossincrático, na forma de um retorno do desejo reprimido pela mimese, que é colocado a serviço do antissemitismo organizado. O fascismo aperfeiçoa esta técnica ao dar a seus seguidores permissão para agir mimeticamente no ritual fascista e no teatro público, mas também no mimetismo sádico dos judeus, que se tornaram oficialmente alvos de perseguição tolerada por causa de sua presumida recusa a aceitar plenamente as condições repressivas da civilização baseada na racionalidade esclarecida. Horkheimer e Adorno escrevem:

O fato de que o indivíduo que tem raízes vê no que o diferencia do judeu a igualdade, o humano, induz nele o sentimento de antagonismo e de estranheza. É assim que os impulsos que são objeto de tabus e contrários ao trabalho em sua forma dominante são convertidos em idiossincrasias conformistas. (...) É só assim sob o disfarce da acusação que o desejo subliminar dos autóctones de retornar à prática mimética do sacrifício pode ressurgir em sua consciência. E quando todo o horror dos tempos primitivos abolidos pela civilização é reabilitado como um interesse racional pela projeção sobre os judeus, não há mais como parar (DoE, pp.152-153 [152-153]).

Em outras palavras, a dominação da natureza "esclarecida" é aperfeiçoada a um tal ponto que até mesmo os impulsos rebeldes são apropriados e colocados a serviço da dominação racional do homem pelo homem, que atinge novos graus de perfeição no fascismo. ${ }^{25}$

Embora Horkheimer e Adorno afirmem que o nível de repressão da mimese aumenta na sociedade burguesa moderna, ${ }^{26}$ este aspecto de sua argumentação permanece subdesenvolvido e marginal em relação à afirmação mais básica de que tal repressão é “a condição da civilização" como um todo. Como tal, o argumento padece da mesma fraqueza que a tese mais ampla sobre a dominação da natureza, na medida em que repousa sobre um conceito trans-histórico de repressão. 0 argumento não aborda as formas específicas em que os níveis de repressão e as diferentes formas

24 Em sua resposta a Adorno, Horkheimer recomenda que eles incluam as reflexões de Adorno sobre a história primitiva do antissemitismo em um excurso sobre Freud, como a última tese sobre antissemitismo no capítulo final de seu projeto colaborativo - que se tornaria a Dialética do Esclarecimento. Cf. MHGS, 16, p.765.

25 Horkheimer desenvolve uma versão diferente, mais específica historicamente, deste argumento em “A revolta da natureza”, o terceiro capítulo de Eclipse da razão. Cf. Horkheimer, 1974, pp.92127.

26 Eles escrevem: “No modo de produção burguês, a indelével herança mimética de toda práxis é abandonada ao esquecimento" (DoE, p.149 [150]). 
de sua manipulação variam em períodos e sociedades distintos. Seu argumento aqui parece postular a existência de um "antissemitismo eterno" - ou de um antissemitismo coextensivo com a civilização doméstica como tal - do tipo categoricamente criticado por Hannah Arendt e outros (cf. Arendt, 1968, pp.7-10). Em contraste com Eros e a civilização, de Marcuse, e com os primeiros escritos de Horkheimer, nos quais há uma tentativa de distinguir entres níveis de repressão necessários e excedentes, que variam com base no desenvolvimento da sociedade burguesa moderna (cf. Marcuse, 1955, pp.78-105), as formas "idiossincráticas" de antissemitismo são fundadas em uma teoria da repressão da mimese característica da "civilização" como um todo concebida como "a vitória da sociedade sobre a natureza" (DoE, p.153 [153]) - que se assemelha intimamente ao conceito trans-hitórico de princípio de realidade que pode ser encontrado em $O$ mal-estar na civilização e em outros escritos de Freud. 0 esforço louvável de Horkheimer e Adorno em abordar os impulsos reprimidos como a fonte da energia que é canalizada em preconceito antissemita também deixa em aberto a questão de se reprimir a mimese é ou não a mesma coisa que reprimir um impulso. Em todo caso, várias das outras teses sobre o antissemitismo fornecem análises mais convincentes e historicamente específicas; por exemplo, Horkheimer e Adorno vinculam o “antissemitismo burguês” à ocultação da dominação na produção, específica do capitalismo moderno. Eles reconhecem que formas políticas populares e völkisch de antissemitismo estavam vinculadas à emergência de novas formas de nacionalismo radical e populismo de direita na Europa do fim do século XIX, que representaram, por sua vez, uma nova fase no desenvolvimento contraditório da sociedade burguesa. Sem estas teorias histórico-críticas, a explicação genealógica das fontes arcaicas do antissemitismo tem pouco poder explanatório.

\section{Resquícios do primeiro conceito de Esclarecimento de Horkheimer na Dialética do Esclarecimento}

A seguir, gostaria de apontar para uma tendência contraposta, historicamente específica, na Dialética do Esclarecimento, que reconhece os momentos qualitativamente novos, críticos e utópicos do Esclarecimento no período moderno, mas ao mesmo tempo descreve o modo como são suprimidos em decorrência da transformação histórica da sociedade burguesa nos séculos XVIII, XIX e XX. Considero que esta tendência deveria ser considerada principalmente como um resquício do conceito mais positivo de Esclarecimento desenvolvido por Horkheimer no fim dos anos 1920 e nos anos 1930. Assim, não é surpreendente que esta tendência seja mais visível no segundo excurso, "Juliette ou Esclarecimento e moral", que os estudiosos agora sabem ter sido escrito principalmente por Horkheimer. ${ }^{27}$ Como vimos, Horkheimer

27 Veja-se a nota 14, acima. 
se aproximou da compreensão de Esclarecimento de Adorno no fim dos anos 1930 e começo dos anos 1940, ${ }^{28}$ o que explica a predominância desta visão na Dialética do Esclarecimento como um todo; no entanto, traços significativos da posição inicial de Horkheimer são ainda visíveis no texto, como gostaria de demonstrar a seguir.

A tendência a uma interpretação historicamente específica do Esclarecimento difere da tendência dominante em vários aspectos importantes. Por exemplo, enfatiza o caráter qualitativamente novo do Esclarecimento no período moderno, que é mais crítico e utópico do que qualquer forma anterior do Esclarecimento. Além disso, é baseado em uma interpretação materialista da sua transformação no contexto mais amplo da transformação da sociedade burguesa no século XIX. Considere-se a seguinte citação:

O Esclarecimento dos tempos modernos esteve desde o começo sob o signo da radicalidade: é isso que o distingue de toda etapa anterior da desmitologização. (...) o Esclarecimento não se detém nem mesmo diante do mínimo de fé sem o qual o mundo burguês não pode subsistir. Ele não presta à dominação os serviços confiáveis que as antigas ideologias sempre lhe prestaram. Sua tendência antiautoritária - que (...) se comunica com a utopia implícita no conceito de razão - acaba por torná-la tão hostil à burguesia estabelecida quanto à aristocracia, da qual aliás logo se tornou também uma aliada (DoE, pp.72,73 [79]).

Certamente, mesmo esta concepção nova, mais crítica e utópica do Esclarecimento foi logo minada e derrotada, mas a causa desta derrota não é buscada fundamentalmente em sua continuidade com formas anteriores do Esclarecimento. Sua derrota é vinculada à transformação da própria sociedade burguesa. Eles escrevem: “Atrelado ao modo de produção dominante, o Esclarecimento, que se empenha em solapar a ordem tornada repressiva, dissolve-se a si mesmo" (DoE, pp.73-4 [80]).

Nesta seção do excurso “Juliette”, Horkheimer e Adorno também apontam para os modos como os momentos críticos e utópicos do Esclarecimento moderno são dissociados e preservados: idealmente, na filosofia e na música alemãs, e, praticamente, no movimento socialista do século XIX. Eles escrevem: "Depois que a utopia que instilara a esperança na Revolução Francesa penetrou (...) na música e na filosofia alemãs, a ordem burguesa estabelecida funcionalizou completamente a razão" (DoE, p.69 [76-77]). A funcionalização da razão resulta da posição social da burguesia no século XIX como a nova minoria hegemônica. Para que a minoria domine a maioria, as pretensões universalistas do Esclarecimento são reduzidas a um formalismo abstrato, que pode ser usado para denunciar a persistência do universalismo no movimento socialista como "utópico", no mau sentido. 0 formalismo burguês é uma forma de astúcia na medida em que permite a manutenção da dominação social particularista. Ele encontra sua expressão quintessencial na

28 Veja-se a nota 9, acima. 
ideologia da "troca de equivalentes". Eles escrevem: “A astúcia” é um "meio de uma troca onde tudo se passa corretamente, onde o contrato é respeitado e, no entanto, o parceiro é logrado"... Essa irracionalidade da razão na forma de astúcia é "a assimilação da razão burguesa a qualquer razão que a confronta como um poder mais forte” (DoE, p.48 [58], tradução modificada). ${ }^{29}$ No excurso “Juliette”, explicitase a ligação entre a transformação da razão e a resposta burguesa aos movimentos socialistas nos séculos XIX e XX:

a utopia que anunciava a reconciliação da natureza e do eu surgiu com a vanguarda revolucionária de seu esconderijo na filosofia alemã, e se apresentou, de um modo ao mesmo tempo racional e irracional, como a Ideia de uma associação de homens livres, atraindo para si toda a fúria da ratio (DoE, p.71 [78]).

É evidente que esta nova forma de razão antiutópica - na verdade contrarrevolucionária - que toma forma nas décadas intermediárias do século XIX é algo qualitativamente diferente da concepção crítica e utópica do Esclarecimento que o primeiro Horkheimer encontra no Esclarecimento francês. ${ }^{30}$

Até mesmo nos dois últimos capítulos da Dialética do Esclarecimento, que foram escritos ou conjuntamente ou predominantemente por Adorno, pode-se encontrar traços significativos do conceito historicamente específico de Esclarecimento. Por exemplo, justapostos em tensão com sua análise da idiossincrasia e da repressão da mimese no capítulo sobre "Elementos do antissemitismo", pode-se encontrar a seguinte passagem, que ao mesmo tempo celebra o Esclarecimento histórico e descreve a sua degeneração como um resultado da consolidação da hegemonia burguesa no século XIX. Horkheimer e Adorno escrevem:

Com a propriedade burguesa, a cultura também se difundiu. Ela havia empurrado a paranoia para os recantos obscuros da sociedade e da alma. Mas como a real emancipação dos homens não ocorreu ao mesmo tempo que o Esclarecimento do espírito, a própria cultura ficou doente. Quanto mais a realidade social se afastava da consciência cultivada, tanto mais esta se via submetida a um processo de reificação (DoE, p.163 [162]).

Aqui, como nos exemplos já mencionados do capítulo “Juliette”, os autores explicam a derrota do Esclarecimento histórico não em termos de seus próprios vícios arcaicos, mas como um resultado da transformação da sociedade burguesa nos séculos XIX e $X X$. De acordo com esse argumento historicista crítico e materialista, em outras

29 Horkheimer e Adorno estão claramente referindo-se à crítica de Marx da ideologia liberal burguesa da "troca de equivalentes", que, como Marx demonstra, é contradita pela extração de mais-valia.

30 Não é por acaso que em seu estudo dos anos 1940, Razão e revolução, Herbert Marcuse reconstrói a transformação, durante começo e meados do século XIX, do conceito negativo e crítico de razão do Esclarecimento - que havia sido preservado na filosofia de Hegel - em uma noção afirmativa e positiva de razão, que se encontra no trabalho de Saint-Simon e Comte. 0 estudo de Marcuse, que foi concebido no final dos anos 1930 em colaboração com Horkheimer, deveria apresentar algumas das pressuposições filosóficas chaves da Teoria Crítica para um público de língua inglesa. 
palavras, a dialética do Esclarecimento é o resultado de uma dialética mais profunda da sociedade burguesa moderna.

O capítulo “Indústria cultural” também pode ser reinterpretado nesse sentido. Seu subtítulo, "o Esclarecimento como mistificação das massas [mass deception (Massenbetrug)]", ${ }^{31}$ surpreende o leitor ao contradizer de modo flagrante uma das mais fundamentais, se não a mais fundamental, característica do Esclarecimento histórico, a saber, o movimento para disseminar o conhecimento de modo a emancipar as "massas" não-educadas - e a humanidade como um todo - da autoridade irracional e do mito. Nada sublinha mais completamente a asserção de Horkheimer e Adorno de que o Esclarecimento se converte em seu oposto do que a acusação de que degenerou em "mistificação das massas" [mass deception]. De fato, seu próprio uso do conceito de Esclarecimento para descrever uma técnica de "mistificação das massas" [mass deception] sublinha a própria impossibilidade de compreender o Esclarecimento histórico por meio de seu conceito mais geral de Esclarecimento como dominação da natureza interna e externa, um ponto a que retornarei abaixo. Em todo caso, sua descrição do Esclarecimento como “mistificação das massas” levanta a questão de como e por que esta transformação em seu oposto ocorreu. É porque os conceitos de razão, racionalidade e Esclarecimento na civilização ocidental como um todo eram fatalmente viciados desde o princípio, ou por causa dos mais recentes desenvolvimentos da sociedade burguesa moderna? Vale mencionar novamente que Mudança estrutural na esfera pública: investigações sobre uma categoria da sociedade burguesa, de Jürgen Habermas, fornece evidências extensivas para a segunda interpretação. 0 exame de Habermas do gradual enfraquecimento do papel crítico da esfera pública em termos da transformação mais ampla da sociedade burguesa em diferentes contextos nacionais se assemelha à interpretação do Esclarecimento nos primeiros escritos de Horkheimer. ${ }^{32}$ Aqui, novamente, as vantagens da interpretação histórica em oposição à interpretação trans-histórica do Esclarecimento parecem evidentes.

\section{Conclusão}

Embora traços significativos de uma interpretação historicamente específica do Esclarecimento permaneçam na Dialética do Esclarecimento, eles são ofuscados por uma interpretação trans-histórica, que se baseia na pressuposição de que o Esclarecimento histórico moderno padece dos mesmos vícios que o Esclarecimento sempre portou desde as origens arcaicas da civilização ocidental e que esses vícios são a fonte primária da transformação do Esclarecimento histórico em seu oposto

31 Nota da tradutora: em inglês, Massenbetrug foi traduzido como "Mass Deception", opção seguida por John Abromeit. Uma vez que em português, espanhol e francês a opção consagrada foi "mistificação", são apresentadas aqui as duas possibilidades.

32 Veja-se uma discussão mais detalhada sobre esta questão no item II, acima. 
nos tempos mais recentes. Mas os esforços de Horkheimer e Adorno para sustentar este argumento, para demonstrar que o Esclarecimento histórico não é diferentes das formas primeiras do Esclarecimento - que o pensamento burguês sempre foi igual, como Adorno parecia crer $^{33}$-, é carregado de problemas. Este argumento não é contradito apenas por declarações que enfatizam o caráter qualitativamente novo e radical do Esclarecimento histórico, como a citada acima, mas também por apelos explícitos e implícitos a ideais do Esclarecimento histórico que atravessam o livro, o que deixa claro que o Esclarecimento histórico não pode ser simplesmente subsumido sob o conceito mais geral do Esclarecimento como dominação racional. A crítica da indústria cultural coloca foco sobre como ela mantêm seus consumidores em um estado de "selbstverschuldete Unmündigkeit" [menoridade autoimposta] (cf. Kant, 1991, p.54), mas também sobre a eliminação do elemento autoconsciente ativo na cognição, que foi o centro da filosofia teórica de Kant. Suas críticas à dominação da natureza e ao antissemitismo como uma forma de projeção patológica são informadas por uma crítica materialista da epistemologia idealista, que reduz o objeto à pura criação do sujeito. Mas, como observado acima, ${ }^{34}$ o primeiro Horkheimer e outros estudiosos mais recentes do Esclarecimento histórico têm acentuado que a principal tendência epistemológica do Esclarecimento inglês e francês (senão do alemão) era a revolta contra as tendências totalizantes do racionalismo do século XVII e da metafísica racionalista, bem como a reabilitação dos sentidos como fonte de conhecimento, o que também informou o desenvolvimento da estética como uma disciplina filosófica no século XVIII. ${ }^{35}$ Eles acusam o Esclarecimento de reduzir todo o conhecimento ao que é matematicamente quantificável, quando na verdade uma crítica de tais tendências frequentemente caminhou lado a lado com a crítica dos philosophes ao racionalismo. ${ }^{36}$ Eles acusam o Esclarecimento de forçar os indivíduos a "renunciar à pretensão de felicidade" e a suprimir suas emoções (DoE, pp.124,143 [127,143]), quando o Esclarecimento histórico - especialmente na França - era caracterizado por uma reabilitação das paixões e por uma demanda pelo direito não apenas à vida e à liberdade, mas também pela busca da felicidade. ${ }^{37} \mathrm{~A}$ crítica ao antissemitismo de

33 Veja-se a nota 17, acima.

34 Veja-se a nota 4, acima.

35 Para uma discussão acerca da ascensão da estética como uma disciplina no século XVIII e sua relação com o sensualismo filosófico, veja-se Marcuse em Eros e a civilização (Marcuse, 1955, pp,172-185).

36 Para um exemplo da sátira do Esclarecimento francês da tentativa racionalista de compreender o mundo em termos puramente matemáticos, veja-se As cartas persas, de Montesquieu (1964, pp.214-216).

37 Por exemplo, La Mettrie escreve: “A falsa filosofia pode, como a teologia, nos prometer uma felicidade eterna e, embalando-nos em belas quimeras, nos conduzir até lá, ao custo de nossos dias ou de nosso prazer. Muito diferente e mais sabiamente, a verdadeira filosofia nos oferece apenas uma felicidade temporal. Semeia rosas e flores em nosso caminho e nos ensina a recolhêlas" (La Mettrie, 1775, 2, p.102). Sobre a reabilitação do epicurianismo no Esclarecimento francês, 
Horkheimer e Adorno apoia-se na crítica do Esclarecimento histórico ao preconceito, embora eles estejam corretos em enfatizar - comoveremos brevemente- a inadequação da teoria da ideologia dos philosophes. No entanto, sua crítica apela aos ideais de tolerância e cosmopolitismo que eram firmemente defendidos pelos philosophes. Finalmente, Horkheimer e Adorno também apelam ao universalismo e humanismo "genuínos" do começo ao fim da Dialética do Esclarecimento, de modo a criticar o que veem como a degeneração do Esclarecimento em uma nova forma de dominação particularista. A centralidade dos ideais do universalismo e do humanismo para o Esclarecimento histórico em geral e para o Esclarecimento francês, em particular, dificilmente pode ser negado. Se os philosophes compreenderam plenamente ou não as barreiras para a realização destes ideais que se tornariam cada vez mais aparentes no século XIX, é outra questão.

Mesmo em seus primeiros escritos, Horkheimer estava plenamente ciente dos limites do Esclarecimento histórico. Minha intenção aqui não foi minimizar ou ignorar esses limites. O mais notável entre os limites do Esclarecimento histórico, que Horkheimer enfatizou em seus primeiros escritos, foi sua incapacidade de compreender como a estrutura historicamente específica da sociedade influenciou formas existentes de conhecimento e consciência. Mesmo o primeiro Horkheimer reconheceu que o Esclarecimento histórico falhou em elevar o próprio conceito de sociedade ao nível de autorreflexibilidade que seria alcançado posteriormente por Hegel e Marx. ${ }^{38}$ Talvez o mais importante exemplo deste argumento - e que conecta os primeiros escritos de Horkheimer à crítica do antissemitismo na Dialética do Esclarecimento - é sua crítica da teoria da ideologia burguesa, que, sem muito exagero, poderia ser denominada uma "teoria conspiratória da ideologia". Já em uma de suas primeiras publicações, "Origens da filosofia burguesa da história”, Horkheimer contrastou a compreensão de Maquiavel e Hobbes da ideologia como engano consciente e autointeressado de uma maioria dominada pela minoria dominante com aquela de Vico, que antecipou Hegel, Feuerbach e especialmente Marx em sua compreensão mais sofisticada dos determinantes sociais e históricos do conhecimento e do mito. Horkheimer escreve:

se avançarmos na doutrina de Vico com relação à origem histórica da mitologia contra os relatos ingênuos acerca da falsidade dos padres, que foi como o Esclarecimento

veja-se também Thomas Kavanagh, Enlightened Pleasures: Eighteenth-Century France and the New Epicureanism (Kavanagh, 2010).

38 Por exemplo, embora Horkheimer tenha elogiado Voltaire por ter feito importantes contribuições ao estudo da história, que foram muito além dos modelos predominantemente teológicos dos escritos históricos ainda dominantes no decorrer do século XVII, ele também apontou para os limites da pressuposição individualista que guiava seu trabalho: "indivíduos dominados pelo amor de si mesmos são o que Voltaire tenta examinar por trás das lendas históricas ... ele ainda não sabe que a sociedade segue leis diferentes do que o indivíduo e que não se pode estudar a primeira baseada no indivíduo isolado" (MHGS, 9:pp.361-362). 
neste momento ou algumas décadas depois lidou com a religião, apenas então seus feitos aparecem em sua luz própria. (...) Em contraste com o Esclarecimento, Vico nos ensina que falsas religiões se originaram não através da ilusão individual, mas como resultado de um desenvolvimento necessário (...) Ele assim expressa a convicção de que as concepções mitológicas não são criações livres do espírito, mas realidade social, ainda que refletidas de um modo distorcido (MHGS, 2, pp.261-262).

O fato de que a teoria da ideologia como teoria conspiratória do Esclarecimento, que era originalmente voltada a justificar a rebelião progressiva do Terceiro Estado contra a dominação particularista da aristocracia e da monarquia, reapareceria em diferentes circunstâncias históricas na forma do antissemitismo radical e racial dos nacional-socialistas não deixa dúvidas sobre os limites do Esclarecimento histórico ${ }^{39}$ e sobre a necessidade de que a Teoria Crítica da sociedade contemporânea se baseie nos insights mais sofisticados de Marx sobre os determinantes sociais da ideologia. ${ }^{40}$

Neste artigo, identifiquei dois modelos de Esclarecimento nos escritos de Horkheimer e Adorno, que refletem duas abordagens teóricas diferentes. A primeira, que eu acredito que guiou os primeiros escritos de Horkheimer, mas também permanece presente como uma tendência contraposta na Dialética do Esclarecimento, denomino "historicismo crítico" porque é baseada em um esforço para compreender de modo autorreflexivo as condições sociais historicamente específicas que determinaram e continuam a determinar a forma que o Esclarecimento assumiu nas sociedades capitalistas modernas. O segundo modelo, que se tornou dominante na Dialética do Esclarecimento, denomino "genealógico", na medida em que se baseia em um conceito trans-histórico de razão instrumental, que já existia como o telos da racionalidade "burguesa" ou "ocidental" desde sua origem primeira, anterior ao advento da moderna sociedade capitalista. A última interpretação é problemática na medida em que subsume o Esclarecimento histórico sob uma concepção muito mais ampla do Esclarecimento, que é coextensiva com a civilização ocidental como um todo. Esta interpretação não apenas não faz justiça às complexidades e aos aspectos genuinamente emancipatórios do Esclarecimento histórico, mas também falha em compreender o Esclarecimento histórico e sua subsequente degeneração em uma racionalidade "técnica", "instrumental”, "positivista" como o resultado da transformação da sociedade burguesa moderna. Em contraste com o conceito de Esclarecimento que se encontra nos primeiros escritos de Horkheimer, que enfatiza os aspectos críticos, utópicos e emancipatórios do Esclarecimento histórico - sem deixar de considerar os seus limites - na Dialética do Esclarecimento Horkheimer e

39 Para uma ruminação estendida sobre estes temas, veja-se Claussen, 1987. Para uma tentativa de traçar a transformação de outra ideologia popular do Esclarecimento - o discurso dos "produtores virtuosos versus parasitas decadentes" - da Revolução Francesa até o século XIX e sua eventual apropriação pelo fascismo, veja-se Abromeit, 2015, pp.231-264.

40 Para uma discussão estendida destas questões, veja-se o artigo “Ideologie” - Horkheimer e Adorno, 1956, pp.162-181. 
Adorno enfatizam os modos como o Esclarecimento histórico já era dominado pelas tendências instrumentais e positivistas. Nesse sentido, esta interpretação compartilha algumas das fraquezas do inimigo filosófico de Horkheimer, e especialmente de Adorno, Martin Heidegger, com o seu ataque à racionalidade ocidental como um todo por ser fundamentalmente viciosa e a sua falha em explicar as conexões entre as formas dominantes de racionalidade e a estrutura das relações sociais que existem em diferentes épocas históricas (ou mesmo em diferentes períodos históricos nestas épocas). Se uma das características essenciais do pensamento dialético é a autorreflexibilidade crítica, histórica, o conceito de Horkheimer e Adorno de Esclarecimento, como uma forma de dominação da natureza inerente à civilização ocidental como um todo, deixa a desejar nesse aspecto.

\section{Referências}

Abromeit, J. (2006). “The Vicissitudes of the Politics of 'Life': Herbert Marcuse and Max Horkheimer's Reception of Phenomenology and Vitalism in Weimar Germany". University of Indiana Scholar Works. Disponível online: https://scholarworks. iu.edu/dspace/handle/2022/440 (acessado em 16.01.2017).

. (2011). Max Horkheimer and the foundations of the Frankfurt School. New York: Cambridge University Press.

(2013). "Max Horkheimer et le concept matérialiste de la culture". In: Les normes et le possible: Héritage et perspectives de l'École de Francfort. G. Raulet, P. F. Noppen, and I. Macdonald (eds.). Paris: Maison des sciences de l'homme, pp.53-70.

(2015). "Transformations of Populism in Western Europe". In: Transformations of Populism in Europe and the Americas: History and Recent Tendencies, Abromeit et al (eds.). London: Bloomsbury.

Adorno, T. W. (1998). "Scientific Experiences of a European Scholar in America". In: Critical Models: Interventions and Catchwords. Translated by Henry Pickford. New York: Columbia University Press.

Arendt, H. (1968). The Origins of Totalitarianism. New York: Harcourt.

Bates, D. W. (2002). Enlightenment Aberrations: Error and Revolution in France. Ithaca, NY: Cornell University Press.

Benhabib, S.; Bonss, W.; McCole, J. (org). (1993). On Max Horkheimer. New Perspectives. Cambridge, Massachusetts, London: The MIT Press.

Buck-Morss, S. (1977). The Origin of Negative Dialectics: Theodor W. Adorno, Walter Benjamin, and the Frankfurt Institute. New York: Free Press.

Calhoun, C. (ed.). (1992). Habermas and the Public Sphere. Cambridge, MA: MIT Press.

Claussen, D. (1987). Grenzen der Aufklärung: Die gesellschaftliche Genese des modernen Antisemitismus. Frankfurt: Fischer. 
Elias, N. (1982). The Civilizing Process. Translated by Edmund Jephcott. Malden, MA: Blackwell.

Gay, P. (1966). The Enlightenment: An Interpretation, vol. 1, The Rise of Modern Paganism. New York: Norton. (1969). The Enlightenment: An Interpretation, vol. 2, The Science of Freedom. New York: Norton.

Habermas, J. (1989). The Structural Transformation of the Public Sphere: An Inquiry into a Category of Bourgeois Society. Translated by T. Burger. Cambridge, MA: MIT Press [tradução brasileira de Denilson Luís Werle. São Paulo: Vozes, 2014].

Horkheimer, M. (1987). Gesammelte Schriften, vols. 9-10. Alfred Schmidt and Gunzelin Schmid Noerr (eds.). Frankfurt: Fischer.

Horkheimer, M. and Adorno, T. W. (2002). Dialectic of Enlightenment: Philosophical Fragments. Edited by. Gunzelin Schmid Noerr and translated by Edmund Jephcott. Stanford, CA: Stanford University Press [Tradução brasileira: Dialética do Esclarecimento fragmentos filosóficos. Tradução de Guido Antonio de Almeida. Rio de Janeiro: Jorge Zahar, 2006].

(1956). "Ideologie”. In: Frankfurter Beiträge zur Soziologie, vol. 4, Soziologische Exkurse. Theodor W. Adorno and Walter Dirks (eds.). Frankfurt: Europaïsche Verlagsanstalt.

Jenemann, D. (2007). Adorno in America. Minneapolis: University of Minnesota Press.

Kant, I. (1991). “An Answer to the Question: What Is Enlightenment?”. Translated by H. B. Nisbet. In: Political Writings. Hans Reiss (ed.). Cambridge: Cambridge University Press.

Kavanagh, T. (2010). Enlightened Pleasures: Eighteenth-Century France and the New Epicureanism. New Haven, CT: Yale University Press.

La Mettrie. (1775). “Discours sur le Bonheur”. Oeuvres Philosophiques. Berlin.

Marcuse, H. (1955). Eros and Civilization: A Philosophical Inquiry into Freud. Boston: Beacon.

Marx, K. (1967). Capital. New York: International Publishers.

(1978). “Introduction to The Grundrisse”. In: Robert C. Tucker (ed.). The Marx-Engels Reader. 2nd ed. New York: Norton.

. (1978a). “The German ideology”. In: Robert C. Tucker (ed.). The Marx-

Engels Reader. 2nd ed. New York: Norton.

McCormick, J. P. (2007). Weber, Habermas, and Transformations of the European State: Constitutional, Social, and Supranational Democracy. Cambridge: Cambridge University Press.

Montesquieu (1964). The Persian Letters. Translated by George R. Healy. Indianapolis: Bobbs-Merrill.

Nietzsche, F. (1969). On the Genealogy of Morals and Ecce Homo. Translated by W. Kaufmann and J. Hollingdale. New York: Vintage.

Noerr, G. S. (2002). “Editor's Afterword”. In: Horkheimer, M. and Adorno, T. W. 
Dialectic of Enlightenment: Philosophical Fragments. Edited by. Gunzelin Schmid Noerr and translated by Edmund Jephcott. Stanford, CA: Stanford University Press.

Postone, m. (1993). Time, Labor, and Social Domination: A Reinterpretation of Marx's Critical Theory. Cambridge: Cambridge University Press.

Schorske, C. and Bender, T. (eds.). (1997). American Academic Culture in Transformation: Fifty Years, Four Disciplines. Princeton, NJ: Prince- ton University Press.

Schuster, M. (2014). Adorno, German Idealism, and Modernity. Chicago: University of Chicago Press.

Sewell, W. (2005). Logics of History: Social Theory and Social Transformation. Chicago: University of Chicago Press.

Wheatland, T. (2009). The Frankfurt School in Exile. Minneapolis: University of Minnesota Press.

Wolin, R. (1994). Walter Benjamin: An Aesthetic of Redemption. Berkeley: University of California Press. 